\title{
HAZ Characterization of Automotive DP Steels by Physical Simulation
}

\author{
R. SISODIA ${ }^{1}$, M. GÁSPÁR², N. GUELLOUH ${ }^{3}$ \\ ${ }^{1}$ Institute of Materials Science \& Technology, Faculty of Mechanical Engineering \& Informatics, University of \\ Miskolc, Hungary, metraghu@uni-miskolc.hu \\ ${ }^{2}$ Institute of Materials Science \& Technology, Faculty of Mechanical Engineering \& Informatics, University of \\ Miskolc, Hungary, gasparm@uni-miskolc.hu \\ ${ }^{3}$ Institute of Energy and Chemical Machinery, University of Miskolc, Hungary, \\ noureddine.guellouh94@gmail.com
}

Abstract. DP steels were extensively used in the vehicles industry due to its extraordinary combined properties of strength, ductility, formability and weldability which contributed great significance in reducing strength to weight ratio and $\mathrm{CO}_{2}$ emission. High strength steel i.e. DP steels (3 different grades) were experimentally investigated and thermophysically simulated using Gleeble 3500 simulator to determine softening and hardening in heat affected zone. Samples were heated to different peak temperatures $\left(1350{ }^{\circ} \mathrm{C}, 950{ }^{\circ} \mathrm{C}, 775{ }^{\circ} \mathrm{C}\right.$ and $\left.650{ }^{\circ} \mathrm{C}\right)$, two cooling time $\left(t_{8.5 / 5}\right.$ $=5 \mathrm{~s}$ and $30 \mathrm{~s})$ and Rykalin $2 \mathrm{D}$ model were selected. The hardness and microstructure of the specimens were tested and analysed. For longer cooling time $\left(t_{8.5 / 5}=30 \mathrm{~s}\right)$, we observed that softening occurs in all grade of investigated DP steels to all sub-regions. But for shorter cooling time i.e. $t_{8.5 / 5}=5 \mathrm{~s}$ the softening is higher in intercritical HAZ compared to other sub-regions for all the types of DP steel with short cooling time $\left(t_{8.5 / 5}=5 \mathrm{~s}\right)$. However, the hardening zone in the CGHAZ occurs when $T_{\max }$ is $1350{ }^{\circ} \mathrm{C}$ for DP600, DP800 \& DP1000 steels but it is more prominent in DP800 as compared to others two steel grade.

Keywords. Dual phase steels, Physical simulation (Gleeble 3500), Heat affected zone (HAZ), Ryaklin 2D model, $t_{8.5 / 5}$ cooling times.

\section{Introduction}

DP steels are a group of low-carbon micro-alloyed steels and the term 'dual phase' indicates that the steel has two distinct phases, i.e., martensite and ferrite [1]. DP600, DP800 \& DP1000 is called DP (Dual Phase), the "double - phase" fabric structure of the steel, while the $600,800 \& 1000$ refer to the required minimum guaranteed value of tensile strength in MPa [2]. Martensite is a very hard phase with body-centered tetragonal structure, while ferrite is a relatively soft phase with a body centered crystal structure [3]. This microstructure with ferritic grain matrix and martensite islands have considerable amount of bainite depending on the process route and steel composition of hot rolled strips. [4]. Therefore, DP steels possess high strength and good ductility properties [5,6], excellent energy absorption during impact $[7,8,9]$. The DP steels are used in car body, safety parts, and chassis [10-11]. The chemical composition of DP steels is low carbon content, minimal alloying elements and 
low $\mathrm{S}, \mathrm{P}, \mathrm{O}$ and $\mathrm{N}$ content. The average $\mathrm{C}$ content of different grades of DP steels varies between 0.1 to $0.15 \%$. As we know, the C content is important for DP steels as martensite besides its volume ratio, to strengthen DP steels. The disadvantage of increasing $C$ content, to reduce the weldability, reduce the impact and increases the transition temperature and therefore in industrial practice the DP steels with a C content of less than $0.15 \%$ were widely used. For the strength, the Mn content of DP steels increases and resulted in fine dispersion of martensite leading to higher tensile strength and good ductility. The usual amount of $\mathrm{Mn}$ is $0.5-2.0 \%$ concentrate [12]. Depending on martensite volume fraction, the tensile strength $\left(R_{m}\right)$ ranges from 500 to about $1000 \mathrm{MPa}$, and total elongation amounts to $12-34 \%$. The dual-phase structure of these steels results in adequately low yield stress $\left(R_{e}\right)$ and high ultimate tensile strength $\left(R_{m}\right)$, allowing for obtaining sufficiently low $R_{e} / R_{m}$ ratio. Soft ferrite facilitates the beginning of plastic deformation, while hard martensite increases the strength of steel $[13,14,15]$. DP steels show high strain-hardening coefficient $n$, which determines the maximum allowable stretch of sheets. A higher $n$-value compared to a lower one means a deeper part can be stretched. Microstructural internal stresses occurring during martensite formation increase the density of mobile dislocations that facilitate the beginning of plastic deformation and prevent from the occurrence of discontinuities at the physical yield point [16].

The automotive sheets are mostly joined by some kind of resistance and arc welding process, or in some special cases (e.g. in the case of poorly weldable or non-weldable materials) by joining methods belonging to the welding related technologies. As a result of innovations and developments in recent years, among automotive joining technologies we can observe the application and slow expansion of processes such as adhesive bonding, soldering and various mechanical methods (riveting, clinching, etc.) [17].

In this paper, three different grade of DP steels were compared for hardening and softening mechanism that occurs in all four different sub-zones HAZ of thermophysically simulated specimens. In addition, different heat inputs have different effects on softening and hardening of simulated specimens [18]. Several experimental studies shown that the higher the strength grade of high strength steel is, the more severe the softening take place. Softening of HAZ decreases the strength, plasticity, formability and fatigue performance of the welded joint [19-20], which affects service performance. Due to global environment, climate change and fuel crisis, the demand for lightweight vehicles has increased over the last few decades [21-22]. This approach played the important role in development of high strength steel like DP steels etc. with higher strength [23], better formability (A measure of formability is the product of strength and uniform elongation) [24] and good weldability as compared to the conventional steels for the same strength with greater reduction of weight $[21,25$, $26,27]$. Also, companies around the globe are continually advancing the state of the art of these alloys in terms of finetuned composition, heat treatments, and coating technologies [28]. 


\section{Experiment Details}

A Gleeble 3500 thermomechanical simulator was used to simulate the welding thermal cycles of all the sub zones of the heat-affected zone for Gas Metal Arc Welding (GMAW) of DP steel. Square base specimen $(1 \mathrm{~mm} \times 10 \mathrm{~mm} \times 70 \mathrm{~mm})$ were prepared and subjected to thermal cycles. The thermal cycle parameters were selected according to the possible procedures during the gas metal arc welding. In order to simulate the sub-zones of the heat-affected zone $[29,30]$, samples were heated to different peak temperatures $\left(1350{ }^{\circ} \mathrm{C}, 950{ }^{\circ} \mathrm{C}, 775{ }^{\circ} \mathrm{C}\right.$ and $\left.650{ }^{\circ} \mathrm{C}\right)$, two cooling time $\left(\mathrm{t}_{8.5 / 5}=5 \mathrm{~s}\right.$ and $\left.30 \mathrm{~s}\right)$ and Rykalin 2D model were selected. By using inbuilt software with thermophysical simulator, QuikSim software, program was created providing given material mechanical properties and some desired input parameters [31]. Heating rate for physical simulation is considered as $500{ }^{\circ} \mathrm{C} / \mathrm{sec}$ and holding time at peak $=0.1 \mathrm{sec}$. The energy input for shorter $\left(\mathrm{t}_{8.5 / 5}=5 \mathrm{~s}\right)$ and longer cooling time $\left(\mathrm{t}_{8.5 / 5}=30 \mathrm{~s}\right)$ were given as $0.88 \mathrm{~kJ} / \mathrm{cm}$ and $2.16 \mathrm{~kJ} / \mathrm{cm}$ respectively.

The programmed HAZ thermal cycles for the two technological variants $5 \mathrm{~s}$ and $30 \mathrm{~s}$ are shown in Figs. $1 \mathrm{a}-\mathrm{b}$ respectively. Due to the time-consuming procedure of determining and testing the HAZ of real welded samples, HAZ physical simulation provides an attractive alternative by enabling the reliable simulation, characterization and testing of different HAZ subzones [32,33,34].
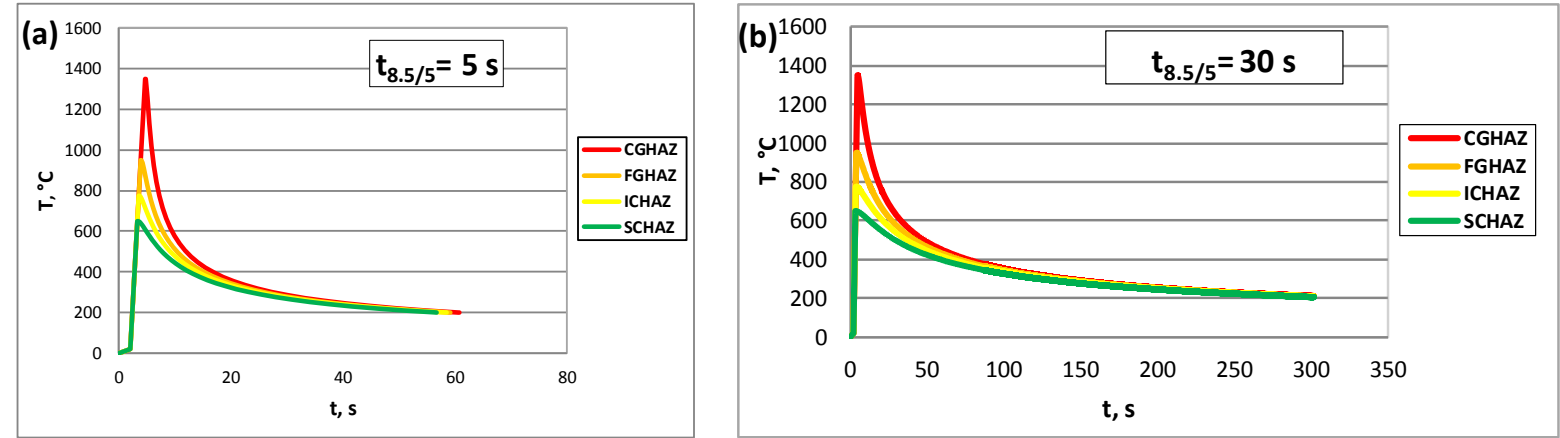

Figure 1. Thermal cycles (a) $t_{8.5 / 5}=5 \mathrm{~s}$ and $(b) t_{8.5 / 5}=30 \mathrm{~s}$

A K(NiCr-Ni) type thermocouple was welded onto the middle of sample for temperature record control during the physical simulation as shown in Figs. 2a-b respectively.
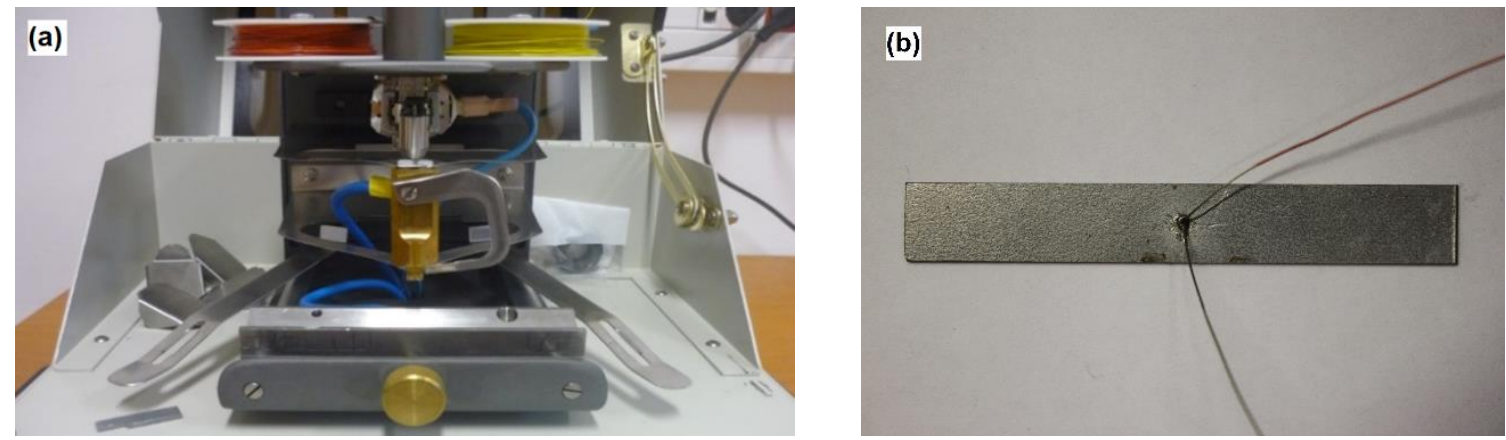

Figure 2. (a) thermocouple welding machine and (b) thermocouple welded on the sample

The hardness and microstructure of the specimens were then tested and analysed using Vicker's hardness test and optical microscope respectively. Samples for microstructures characterization were 
prepared using standard methods and solution used for etching was 2\% Nital. The hardness profiles were obtained across the simulated HAZ samples using Reicherter UH 250 Universal hardness tester with a $10 \mathrm{kgf}$ (or test force of $98.07 \mathrm{~N}$ ) load and with a $10 \mathrm{sec}$ dwell time. A microstructural analysis was carried using an optical microscope (OM) Axio Observer D1m (Zeiss) inverted microscope.

The material investigated was a commercial uncoated cold-rolled DP 600, DP 800 \& DP 1000 steel supplied by Swedish Steel (SSAB) with a thickness of $1 \mathrm{~mm}$ and the steel sheet were cut in the rolling direction. The full chemical composition and the mechanical properties (source: Inspection certificate by material suppliers as mentioned above) of this steel are shown in Table 1 and Table 2 respectively.

Table 1. Chemical composition of the investigated base materials in mass percent

\begin{tabular}{|l|c|c|c|c|c|c|c|c|c|c|c|c|c|c|c|c|}
\hline Steel & $\mathrm{C}$ & $\mathrm{Si}$ & $\mathrm{Mn}$ & $\mathrm{P}$ & $\mathrm{S}$ & $\mathrm{Cr}$ & $\mathrm{Ni}$ & $\mathrm{Mo}$ & $\mathrm{V}$ & $\mathrm{Ti}$ & $\mathrm{Cu}$ & $\mathrm{Al}$ & $\mathrm{Nb}$ & $\mathrm{B}$ & $\mathrm{N}$ & $\mathrm{CEV}$ \\
\hline DP600 & 0.088 & 0.19 & 0.84 & 0.012 & 0.002 & 0.03 & 0.03 & 0.00 & 0.01 & 0.00 & 0.01 & 0.039 & 0.016 & 0.0001 & 0.003 & 0.24 \\
\hline DP800 & 0.136 & 0.20 & 1.55 & 0.013 & 0.003 & 0.03 & 0.04 & 0.00 & 0.01 & 0.00 & 0.01 & 0.046 & 0.016 & 0.0003 & 0.003 & 0.41 \\
\hline DP1000 & 0.132 & 0.19 & 1.50 & 0.010 & 0.003 & 0.03 & 0.03 & 0.00 & 0.01 & 0.00 & 0.01 & 0.041 & 0.014 & 0.0002 & 0.004 & 0.39 \\
\hline
\end{tabular}

Table 2. Mechanical properties of the investigated base materials

\begin{tabular}{|l|c|c|c|}
\hline Steel & $\mathrm{R}_{\mathrm{p} 0.2}, M P a$ & $\mathrm{R}_{\mathrm{m}}, M P a$ & $\mathrm{~A}_{8}, \%$ \\
\hline DP600 & 405 & 650 & 21.0 \\
\hline DP800 & 585 & 871 & 15.5 \\
\hline DP1000 & 821 & 1074 & 9.5 \\
\hline
\end{tabular}

\section{Result and Discussions}

An optical micrograph (M=500x) of DP steels base material DP600, DP800, DP1000 and DP steels contain ferrite grains and islands of martensite enables us to see the microstructures which are shown in Figs. 3a, b, c-d respectively. The samples were etched with the Nital $\left(2 \% \mathrm{HNO}_{3}\right)$, martensite islands appeared black, and ferrite appeared as black. It is evident from the below figure that volume fraction of martensite increasing in higher grades of DP steels base materials in which white grains are ferrites and black one is martensite.
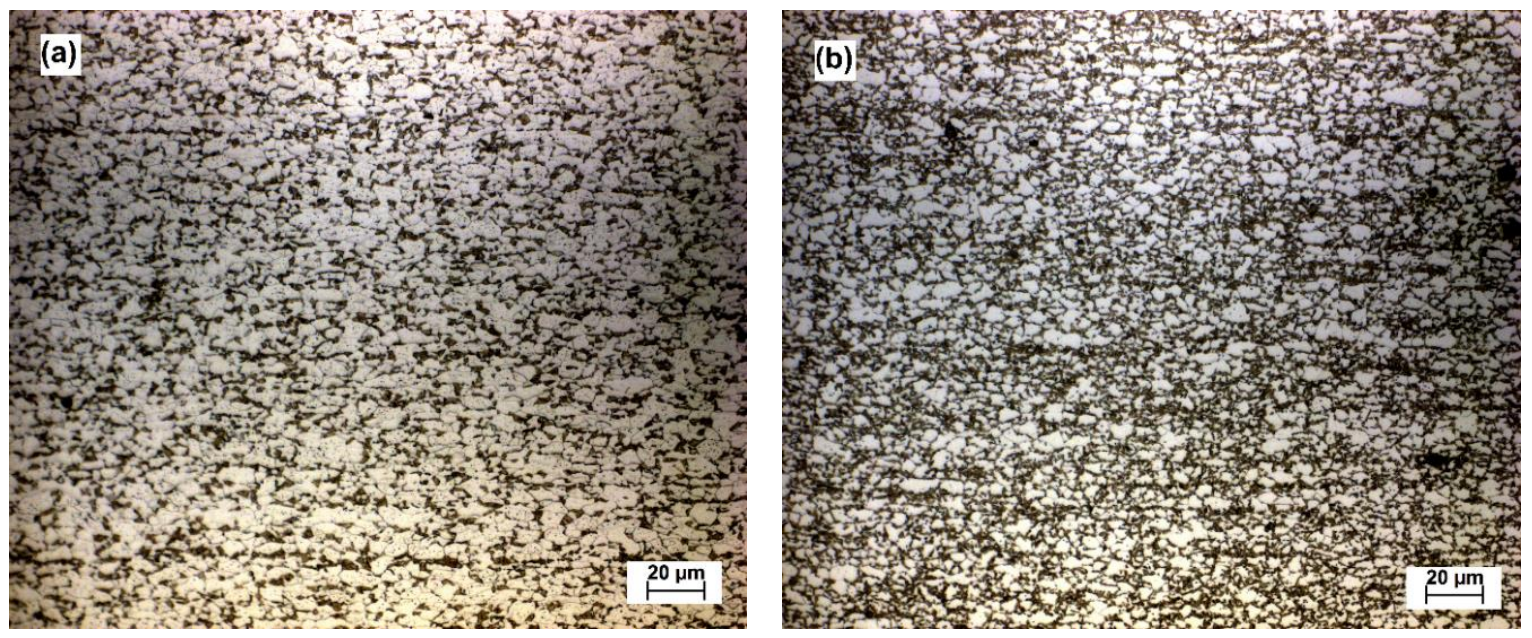

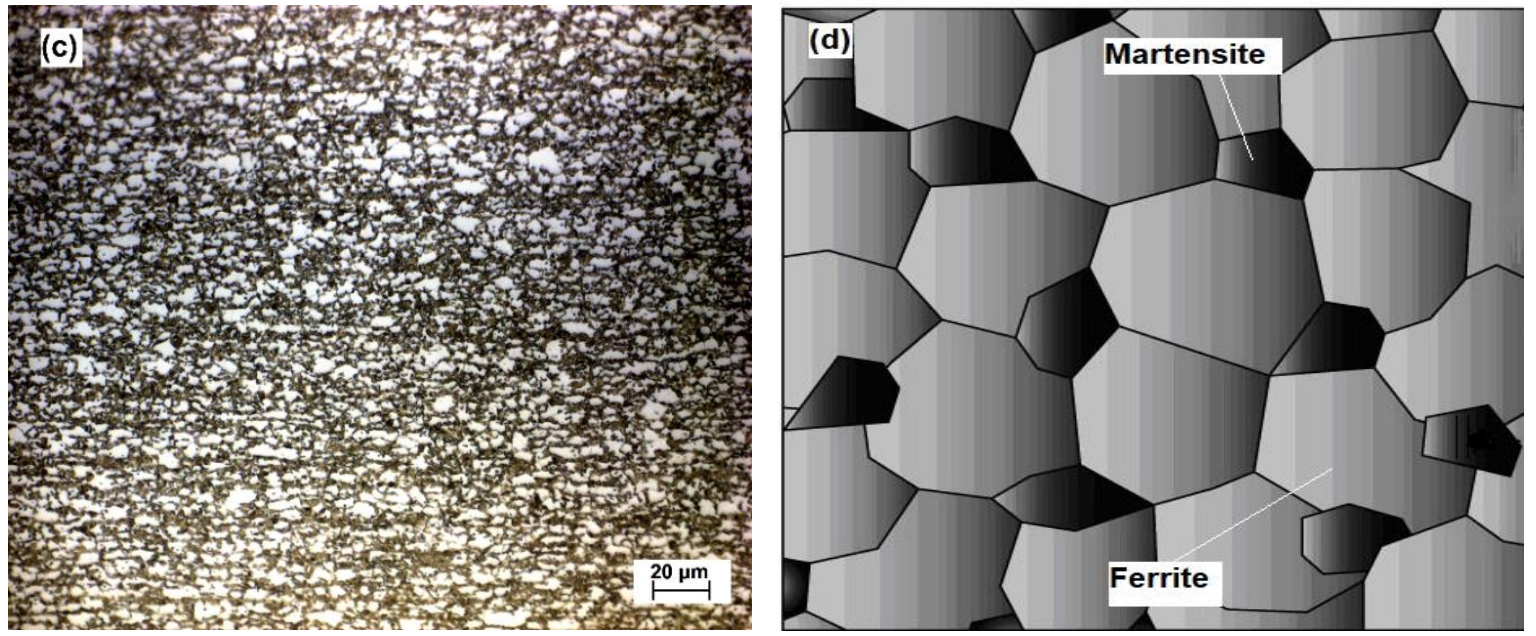

Figure 3. Base materials (a) DP600 (b) DP800 \& (c) DP1000, M=500x. (d) DP steels contain ferrite grains and islands of martensite [35]

The microscopic pictures of coarse-grained heat affected zone, DP600, DP800 and DP1000 steels ( $\mathrm{T}_{\max }$ $=1350{ }^{\circ} \mathrm{C}, 5 \mathrm{~s}$ and $30 \mathrm{~s}$ at $\mathrm{M}=500 \mathrm{x}$ ) as shown in Figs. $4 \mathrm{a}-\mathrm{b}, 5 \mathrm{a}-\mathrm{b} \& 6 \mathrm{a}-\mathrm{b}$ respectively.
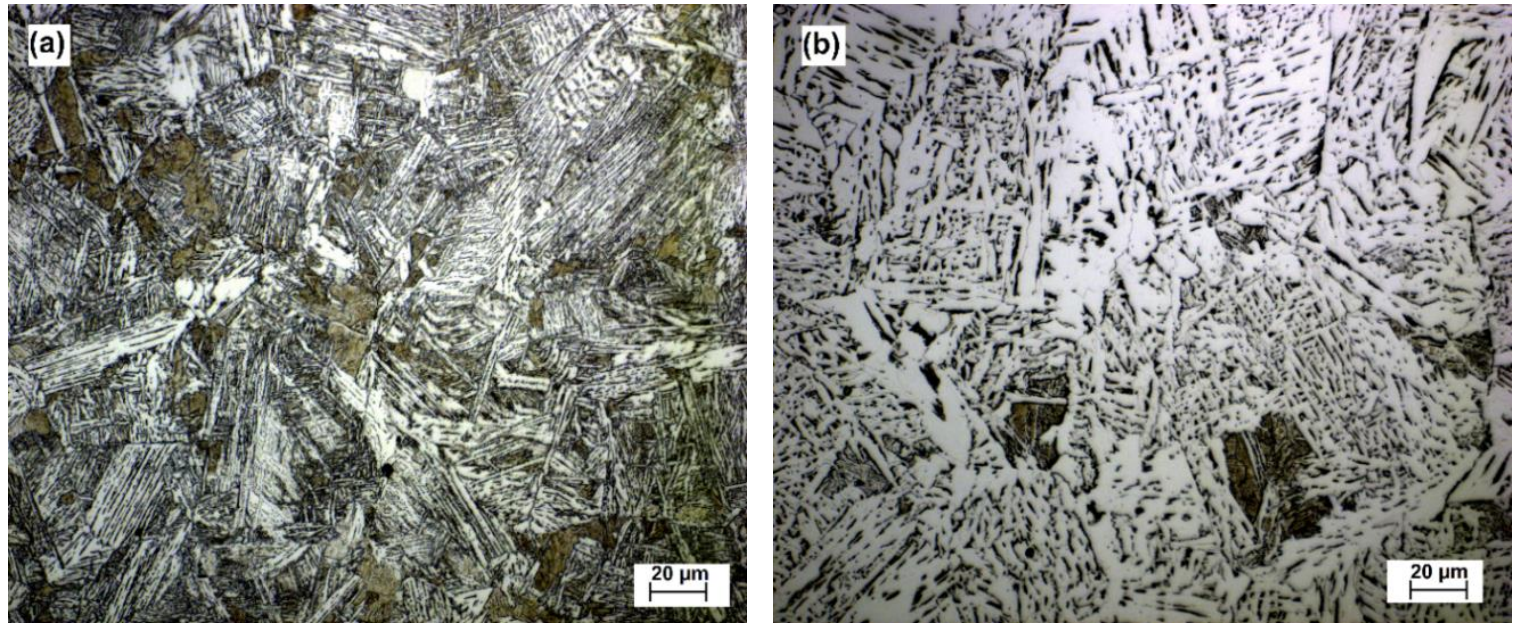

Figure 4. Coarse grained $H A Z(D P 600), T_{\max }=1350^{\circ} \mathrm{C}, M=500 x(a) 5 \mathrm{~s}$ and (b) $30 \mathrm{~s}$
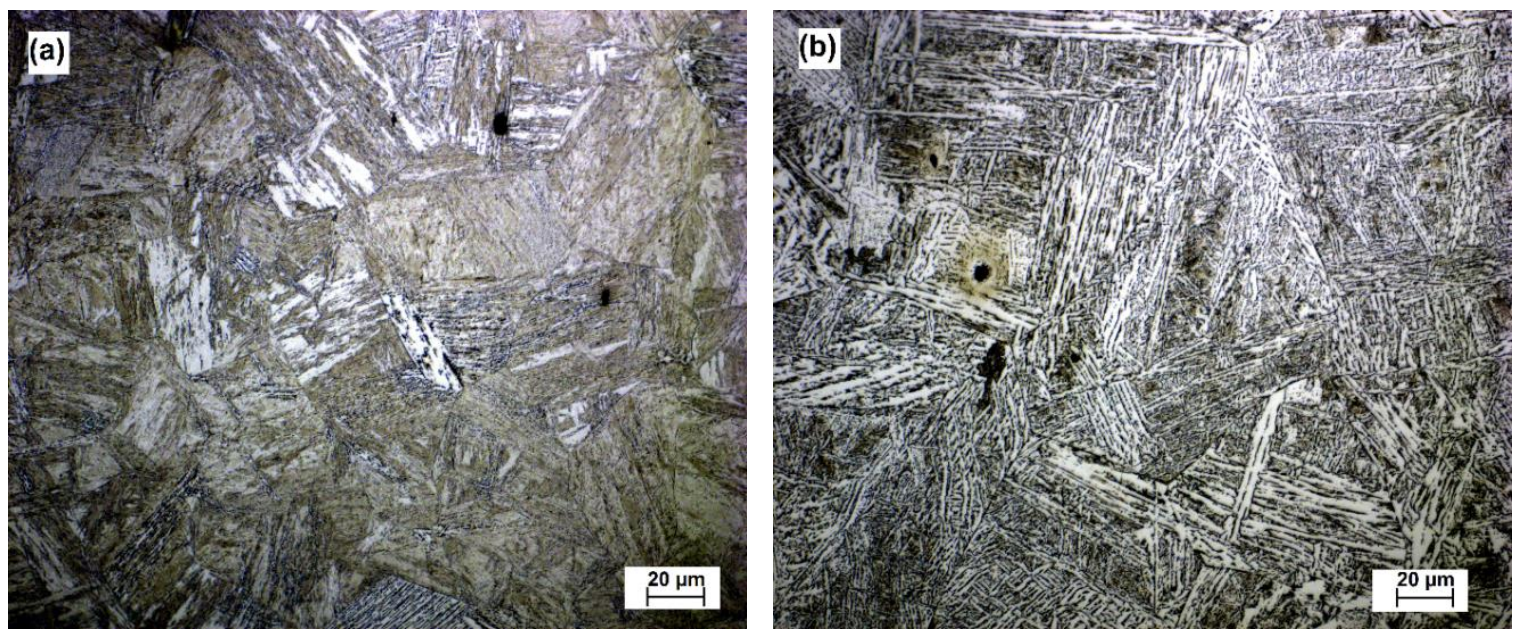

Figure 5. Coarse grained $H A Z$ (DP800), $T_{\max }=1350^{\circ} \mathrm{C}, \mathrm{M}=500 \mathrm{x}(\mathrm{a}) 5 \mathrm{~s}$ and (b) $30 \mathrm{~s}$ 

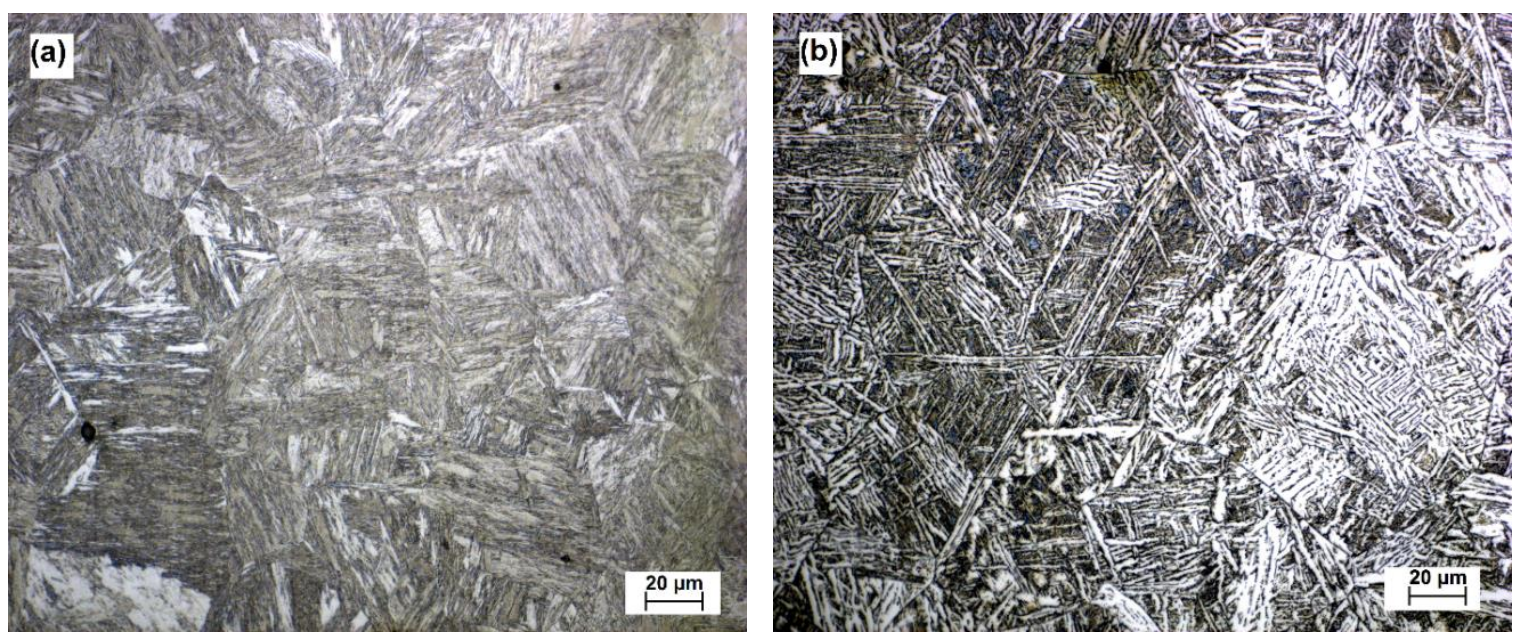

Figure 6. Coarse grained $\operatorname{HAZ}$ (DP1000), $T_{\max }=1350^{\circ} \mathrm{C}, M=500 \mathrm{x}$ (a) $5 \mathrm{~s}$ and (b) $30 \mathrm{~s}$

From microstructural figures we can see that in CGHAZ for shorter cooling time ferrite grains (white) are finer but with longer cooling time it is more coarser and in larger number and these softer grains surrounding the martensitic grains (black). From Fig. 5a, it is observed that for DP800 steel with lower cooling time, tempering of martensite found in some grains but with longer cooling time volume of tempered martensite is higher as shown in figure $5 \mathrm{~b}$. However, the microstructure of each CGHAZ with $\mathrm{t}_{8 / 5}=5 \mathrm{~s}$ is mainly martensite and lower bainite. However, with the longer cooling time the microstructures look different. Especially in DP1000 with $t_{8 / 5}=30 \mathrm{~s}$, the microstructure having the combination of lower and upper bainite and a small fraction of martensite too. The reason for the different transformation microstructures can be found from chemical composition and the CCTdiagram. Martensite formation needs generally fast cooling, while lower and upper bainite are results of slower cooling. Tempering may have some role in the softening of the CGHAZ with $t_{8 / 5}=30 \mathrm{~s}$ compared to $5 \mathrm{~s}$. However, I would say it's mainly because of different microstructures. Martensite generally has the highest hardness before lower bainite and upper bainite, respectively. Also, at high heat input the growth of prior austenite grains decreases the hardness.

The average hardness values for simulated HAZ of DP600, DP800 \& DP1000 in the function of the distance from the fusion line are presented in Figure 7a-b. The average hardness values of the base material of DP steels used in this work were measured by using HV10 hardness test are 207, 270 and 329 for DP600, DP800 and DP1000 respectively. The results show that the simulated HAZ is wider in case of long cooling time compared to short cooling time. The following graphs represent the hardness structure profiles of the simulated HAZ for all types of dual phase steels used (DP600, DP800 \& DP1000), where we can see how the hardness changes in the function of the distance from welding centreline(y). Evaluation was performed according to the EN ISO 15614-1 standard which permits $\mathrm{HV}_{\text {max }}=450 \mathrm{HV} 10$ for non-heat-treated welded joints (including HAZ) of high-strength steels belonging to the group $3^{\mathrm{b}}$ of CR ISO 15608, and $\mathrm{HV}_{\max }=380 \mathrm{HV} 10$ for the groups $\left(1^{\mathrm{a}}, 2\right)$ of CR ISO 15608 also. DP steels are especially not mentioned in the EN ISO 15608 standard, based on their strength and chemical composition they could be classified in group 2 and 3, however they don't include $\mathrm{Mo}, \mathrm{Cr}$ and $\mathrm{Ni}$ which are generally used in quenched and tempered steel belonging to the $3^{\text {rd }}$ group. 

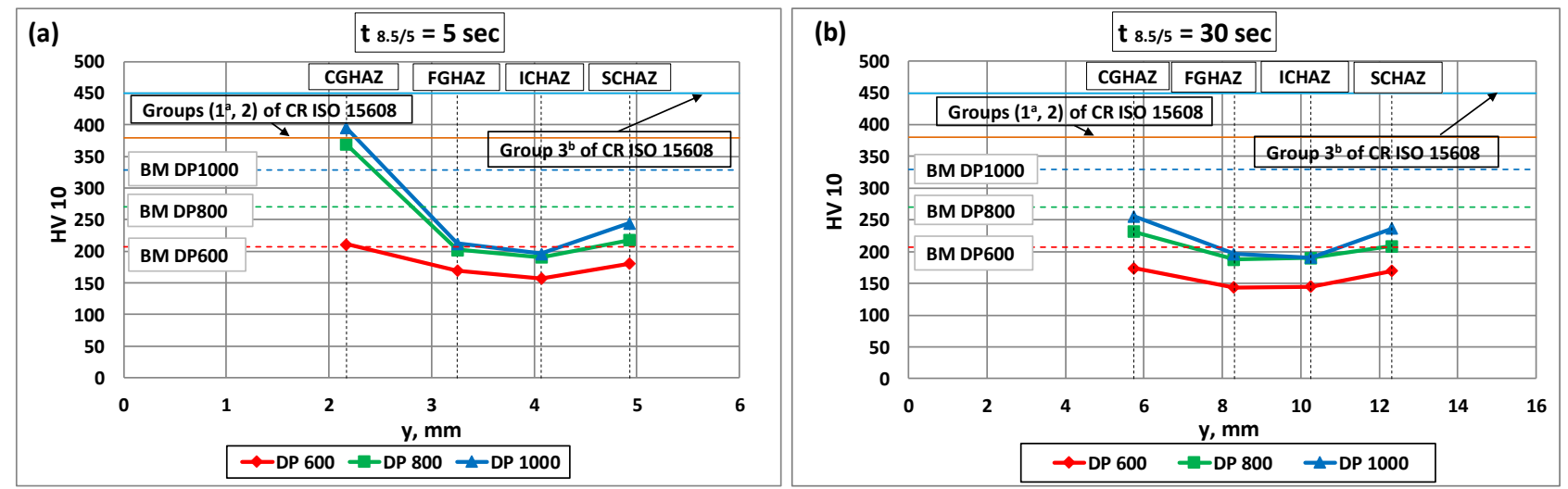

Figure 7. Hardness of simulated HAZ (a) $t_{8.5 / 5}=5 \mathrm{~s}$ and (b) $t_{8.5 / 5}=30 \mathrm{~s}$

The results obtained from the HAZ hardness examinations did not exceed the permitted maximum hardness value for group $3^{\mathrm{b}}$ of CR ISO 15608 (450 HV10), but the hardness values in CGHAZ of DP1000 with short cooling time slightly exceeded the permitted value of $\mathrm{HV}_{\max }$ for groups $\left(1^{\mathrm{a}}, 2\right)$ (380 HV10). Also, we can see that, when $\mathrm{T}_{\max }$ is $1350{ }^{\circ} \mathrm{C}$ and $t_{8.5 / 5}=5 \mathrm{~s}$, the HAZ average hardness of simulated DP600 is slightly higher than base metal, which has an average hardness of $211 \mathrm{HV}$ and ranges from $200 \mathrm{HV}$ to $219 \mathrm{HV}$. The HAZ average hardness of DP800 is significantly higher than base metal, which has an average hardness of $369 \mathrm{HV}$ and ranges from $363 \mathrm{HV}$ to $374 \mathrm{HV}$. For DP1000, hardness is higher than the base metal also exceeded the permitted value of $\mathrm{HV}_{\max }$ for groups $\left(1^{\mathrm{a}}, 2\right)$ (380 HV10). For $\mathrm{T}_{\max }$ $=950{ }^{\circ} \mathrm{C}$ and $t_{8.5 / 5}=5 \mathrm{~s}$, the HAZ average hardness of simulated DP600 is lower than base metal, which has an average hardness of $170 \mathrm{HV}$ and ranges from $163 \mathrm{HV}$ to $177 \mathrm{HV}$. The HAZ average hardness of DP800 is much lower than base metal, which has an average hardness of $203 \mathrm{HV}$ and ranges from 197 $\mathrm{HV}$ to $213 \mathrm{HV}$ and for DP1000, hardness is $213 \mathrm{HV}$ which is much lower than the base metal, ranges from $204 \mathrm{HV}$ to $224 \mathrm{HV}$. Similarly, For $\mathrm{T}_{\max }=775^{\circ} \mathrm{C} \& \mathrm{~T}_{\max }=650{ }^{\circ} \mathrm{C}$ and $\mathrm{t}_{8.5 / 5}=5 \mathrm{~s}$, the average hardness of simulated HAZ is significantly much lower than base metal. Therefore, softening of DP600, DP800 and DP1000 steels can be observed when $\mathrm{T}_{\max }=950{ }^{\circ} \mathrm{C}, 775{ }^{\circ} \mathrm{C} \& 650^{\circ} \mathrm{C}$ for shorter cooling time i.e $\mathrm{t}_{8.5 / 5}=5 \mathrm{~s}$ but the softening is little higher in intercritical HAZ compared to other sub-regions for all the types of DP steel with short cooling time $\left(\mathrm{t}_{8.5 / 5}=5 \mathrm{~s}\right)$. However, the hardening zone in the CGHAZ occurs when $\mathrm{T}_{\max }$ is $1350{ }^{\circ} \mathrm{C}$ for DP600, DP800 \& DP1000 steels but it is more prominent in DP800 as compared to others two steel grade.

For longer cooling time $\left(\mathrm{t}_{8.5 / 5}=30 \mathrm{~s}\right)$, we observed that softening occurs in all grade of investigated DP steels to sub-regions CGHAZ, FGHAZ, ICHAZ and SCHAZ but in general the fine grained HAZ and the intercritical HAZ were the sub-regions where we recorded the highest decrease in hardness for all DP steels. So, we can say that softening occurs almost in all sub-zones with all DP steel grades as the cooling time increases.

\section{Conclusions}

In this study, the physically simulated CGHAZ, FGHAZ, ICHAZ and SCHAZ with two different cooling time $t_{8 / 5}$ were studied and compared for DP600, DP800 \& DP1000 automotive steel. The following observations and conclusions were summarised; 
(a) The performed optical microscopic tests verified that the demanded subzones were successfully created during the physical simulation.

(b) Softening of DP600, DP800 and DP1000 steels can be observed when $\mathrm{T}_{\max }=950{ }^{\circ} \mathrm{C}, 775^{\circ} \mathrm{C} \& 650^{\circ} \mathrm{C}$ for shorter cooling time i.e. $\mathrm{t}_{8.5 / 5}=5 \mathrm{~s}$ but the softening is more in intercritical HAZ compared to other sub-regions for all the types of DP steel with short cooling time $\left(\mathrm{t}_{8.5 / 5}=5 \mathrm{~s}\right)$.

(c) Softening of DP1000 occurs maximum among all sub zones at $\mathrm{T}_{\max }=775{ }^{\circ} \mathrm{C}$ \& longer cooling time i.e. $t_{8.5 / 5}=30 \mathrm{~s}$. A significant softening was noticed in CGHAZ and ICHAZ at the longer cooling times $\left(\mathrm{t}_{8.5 / 5}=30 \mathrm{~s}\right)$ as compared to shorter cooling time $\left(\mathrm{t}_{8.5 / 5}=5 \mathrm{~s}\right)$ for DP1000. However, the hardening zone in the CGHAZ occurs when $\mathrm{T}_{\max }$ is $1350^{\circ} \mathrm{C}$ for DP1000 with short cooling time ( $\mathrm{t}_{8.5 / 5}=5 \mathrm{~s}$ ).

(d) The softening occurs in all grade of investigated DP steels to sub-regions CGHAZ, FGHAZ, ICHAZ and SCHAZ but in general the fine grained HAZ and the intercritical HAZ were the sub-regions where we recorded the highest decrease in hardness for all DP steels.

\section{Acknowledgement}

The presented research work was supported by the European Union and the Hungarian State, cofinanced by the European Regional Development Fund in the framework of the GINOP-2.3.4-15-201600004 project, aimed to promote the cooperation between the higher education and the industry.

\section{References}

[1] R. Davies (1978) Influence of Martensite Composition and Content on the Properties of Dual phase Steels. Metallurgical Transactions A. 9A (5) pp. 671-679.

[2] Á. Dobosy - J. Lukács János (2017) The effect of the filler material choice on the high cycle fatigue resistance of high strength steel welded joints. Materials Science Forum. 885 pp. 111-116.

[3] J. Zhang - A. Khan - O. A. Ojo - N. Zhou - D. Chen (2015) Analysis of Microstructural Changes in the Heat-Affected Zone and Fusion Zone of a Fiber Laser Welded DP980 Steel. The Minerals, Metals \& Materials Society and ASM International 2014. 46B pp. 1638- 1646

[4] M. Brand - D. Siegele (2007) Numerical Simulation of Distortion and Residual Stresses of Dual Phase Steels Weldments, Welding in the World. $51(9 / 10)$

[5] J. Li - S. S. Nayak - E. Biro - S. K. Panda - F. Goodwin - Y. Zhou (2013) Effects of weld line position and geometry on the formability of laser welded high strength low alloy and dual-phase steel blanks. Materials \& Design (1980-2015). 52 pp. 757-766.

[6] M.P. Miles - J. Pew - T.W. Nelson - M. Li (2005) Frict. Stir Weld. Process. 3 pp. 91-96.

[7] J. Pakkanen - R. Vallant - M. Kičin (2016) Experimental investigation and numerical simulation of resistance spot welding for residual stress evaluation of DP1000 steel, International Institute of Welding 2016.

[8] Z. Zheng-zhi - J. Guang-can - N. Feng - T. Di - Z. Ai-min (2009) Microstructure evolution and mechanical properties of 1000 MPa cold rolled dual-phase steel. Trans. Nonferrous Met. Soc. China. 19 pp. 563-568. 
[9] M. Asadi - H. Palkowski (2013) Influence of Load Paths and Bake Hardening Conditions on The Mechanical Properties of Dual Phase Steel. Materials Processing Fundamentals, TMS (The Minerals, Metals \& Materials Society).

[10] L. Rauch - R. Kuziak - M. Pietrzy (2014) From High Accuracy to High Efficiency in Simulations of Processing of Dual-Phase Steels. Metallurgical and Materials Transactions B. 45B p. 497.

[11] W. Ernst - M. Galler - R. Vallant - N. Enzinger (2009) Modification of coupling parameters for a more accurate numerically coupled. Sysweld Forum. Dorint Am Goeathepark, Weimar, Germany.

[12] A. Balogh - L. Prém (2013) Resistance Spot Weldability of Ferrite-Martensite (Dual phase) Steel Sheets. GÉP. 64 (8) pp. 13-17.

[13] A. Bodin - J. Flemming - E.F.M. Jansen (2000) Development of as-hot-rolled low-silicon and micro alloyed dual-phase steels. Proc. of Conf. 42nd MWSP, ISS, Vol. 38, Ontario. pp. 563-571.

[14] M. Dziedzic - S. Turczyn (2006) Mechanical properties of dual phase steel strips obtained in thermomechanical rolling process. Hutnik - Wiadomości Hutnicze. 73 (12) pp. 551-557.

[15] A. Pichler - G. Hribering - R. Angerer (1999) Aspects of the production of dual phase and multiphase steel strips, Proc. of Conf. 41st MWSP, ISS, Vol. 37, Baltimore. pp. 37-59.

[16] M. Dziedzic - S. Turczyn (2010) Experimental and numerical investigation of strip rolling from dual phase steel. Archives of Civil and Mechanical Engineering. 10 (4)

[17] L. Prém - Z. Bézi - A. Balogh (2017) Development of Complex Spot-Welding Technologies for Automotive DP Steels with FEM Support, DOI 10.1007/978-3-319-51189-4_36

[18] E.B. M. Xia - Z. Tian - Y. N. Zhou (2008) ISIJ Int.48, pp. 809-814.

[19] K. Bandyopadhyay - S.K. Panda - P.Saha (2014)J.Mater.Eng.Perform. 23 pp. 1465-1479.

[20] N. Farabi - D.L. Chen - J.Li - Y.Zhou - S.J. Dong (2010) Mat.Sci.Eng. A527 pp. 1215-1222.

[21] M. Eshraghi - M. A. Tschopp - M. A. Zaeem - S. D. Felicelli (2013) A Parametric Study of Resistance Spot Welding of a Dual-Phase Steel Using Finite Element Analysis, The 8th Pacific Rim International Congress on Advanced Materials and Processing, 2013 (TMS) The Minerals, Metals \& Materials Society), pp.3073-3080.

[22] A. Wrozyna - M. Pernach - R. Kuziak - M. Pietrzyk (2016) Experimental and Numerical Simulations of Phase Transformations Occurring During Continuous Annealing of DP Steel Strips. Journal of Materials Engineering and Performance. 25(4) pp. 1481-1491.

[23] B. Varbai - T. Pickle - K. Májlinger (2018) Development and Comparison of Quantitative Phase Analysis for Duplex Stainless Steel Weld. Periodica Polytechnica-Mechanical Engineering. 62 (3) pp. 247-253.

[24] R. W. K. Honeycombe - H. K. D. H. Bhadeshia (1995) Steels: Microstructure and Properties, 2nd Ed. Oxford: Butterworth-Heinemann.

[25] J. Wang - L. Yang - M. Sun - T. Liu - H. Li (2016) A study of the softening mechanisms of laser welded DP1000 steels butt joints. Materials and Design. 97 pp. 118-125. http://dx.doi.org/10.1016/j.matdes.2016.02.071

[26] K. Mukherjee - S.S. Hazra - M. Militzer (2009) Grain Refinement in Dual-Phase Steels, The Minerals, Metals \& Materials Society and ASM International. Metallurgical and Materials Transactions A. 40A, 2145, DOI: 10.1007/s11661-009-9899-9.

[27] Lee, E. M. - Shim, D. S. - Son, J. Y. - Baek, G. Y. - Yoon, H. S. - Ro, K. B. (2016) Study on design of progressive dies for manufacture of automobile structural member using DP980 advanced high strength steel. Journal of Mechanical Science and Technology. 30(2) pp. 853-864. 
[28] G. C. C. Correard - G. P. Miranda - M. S. F. Lima (2016) Development of laser beam welding of advanced high-strength steels. Int. J. Adv. Manuf. Technol. 83 pp. 1967-1977, DOI 10.1007/s00170-015-7701-2.

[29] J. Lukács - L. Kuzsella - Zs. Koncsik - M. Gáspár - Á. Meilinger Ákos (2015) Role of the Physical Simulation for the Estimation of the Weldability of High Strength Steels and Aluminum Alloys. Materials Science Forum 812., pp. 149-154

[30] Á. Dobosy - J. Lukács (2015) Welding Properties and Fatigue Resistance of S690QL High Strength Steels. Materials Science Forum 812 pp. 29-34.

[31] QUIKSIM ${ }^{T M}$ Software heat affected zone programming manual.

[32] H. Tervo - J. Mourujärvi - A. Kaijalainen - J. Kömi (2018) Mechanical Properties in the Physically Simulated Heat-Affected Zones of 500 MPa Offshore Steel for Arctic Conditions, Lecture Notes in Mechanical Engineering. pp. 779-788.

[33] H. Tervo - S. Pallaspuro - A. Kaijalainen - D. Porter - J. Kömi - S. Mehtonen - T. Pikkarainen (2018) Detrimental Effect of Coarse Titanium-Niobium Nitrides on the Fracture Toughness of the CGHAZ in a $500 \mathrm{MPa}$ Offshore Steel for Cold Climate Conditions, Proc. 10th International Conference on Clean Steel, Budapest, Hungary, 2018.

[34] S. J. Heikkilä - D. A. Porter - L. P. Karjalainen - R. O. Laitinen - S. A. Tihinen - P. P. Suikkanen (2013) Hardness Profiles of Quenched Steel Heat Affected Zones, Phys. Numer. Simul. Mater. Process. 762 pp. 722-727. doi: 10.4028/www.scientific.net/MSF.762.722

[35] http://www.worldautosteel.org/wp-content/uploads/2012/03/AHSS-Fig1-2.jpg. 